\title{
Oxidative Stress in the Pathogenesis of Antiphospholipid Syndrome: Implications for the Atherothrombotic Process
}

\author{
Cristina Nocella ${ }^{1}$, Simona Bartimoccia ${ }^{2}$, Vittoria Cammisotto ${ }^{3}{ }^{\oplus}$, Alessandra $^{\prime}$ Amico $^{4}$, Daniele Pastori ${ }^{1}{ }^{1}$,

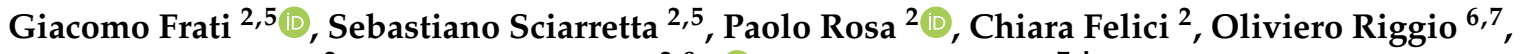 \\ Antonella Calogero ${ }^{2}$, Roberto Carnevale ${ }^{2,8, *}$ (1) and SMiLe Group ${ }^{7,+}$
}

check for updates

Citation: Nocella, C.; Bartimoccia, S.; Cammisotto, V.; D'Amico, A.; Pastori, D.; Frati, G.; Sciarretta, S.; Rosa, P.; Felici, C.; Riggio, O.; et al. Oxidative Stress in the Pathogenesis of Antiphospholipid Syndrome: Implications for the Atherothrombotic Process. Antioxidants 2021, 10, 1790. https://doi.org/10.3390/ antiox10111790

Academic Editor: Raelene Pickering

Received: 29 September 2021

Accepted: 3 November 2021

Published: 9 November 2021

Publisher's Note: MDPI stays neutral with regard to jurisdictional claims in published maps and institutional affiliations.

Copyright: (c) 2021 by the authors. Licensee MDPI, Basel, Switzerland. This article is an open access article distributed under the terms and conditions of the Creative Commons Attribution (CC BY) license (https:// creativecommons.org/licenses/by/ $4.0 /)$.
1 Department of Clinical Internal, Anesthesiological and Cardiovascular Sciences, Sapienza University of Rome, 00161 Rome, Italy; cristina.nocella@uniroma1.it (C.N.); daniele.pastori@uniroma1.it (D.P.)

2 Department of Medical-Surgical Sciences and Biotechnologies, Sapienza University of Rome, 04100 Latina, Italy; simona.bartimoccia@uniroma1.it (S.B.); fraticello@inwind.it (G.F.); sebastiano.sciarretta@uniroma1.it (S.S.); p.rosa@uniroma1.it (P.R.); chiara.feli@gmail.com (C.F.); antonella.calogero@uniroma1.it (A.C.)

3 Department of General Surgery and Surgical Specialty Paride Stefanini, Sapienza University of Rome, 00161 Rome, Italy; vittoria.cammisotto@uniroma1.it

4 Department of Movement, Human and Health Sciences, University of Rome “Foro Italico", 00135 Rome, Italy; a.damico@studenti.uniroma4.it

5 Department of AngioCardioNeurology, IRCCS Neuromed, 86077 Pozzilli, Italy

6 Department of Translational and Precision Medicine, "Sapienza" University of Rome, 00161 Rome, Italy; oliviero.riggio@uniroma1.it

7 Faculty of Medicine and Surgery, Course E, Sapienza University of Rome, 04100 Latina, Italy; smilegrouplatina@libero.it

8 Mediterranea, Cardiocentro, 80122 Napoli, Italy

* Correspondence: roberto.carnevale@uniroma1.it; Tel./Fax: +39-0773-175-7245

+ Membership of the SMiLe Group is provided in the Acknowledgments.

\begin{abstract}
Atherothrombosis is a frequent complication of the clinical history of patients with antiphospholipid syndrome (APS). Both atherothrombosis and APS are characterized by increased oxidative stress. Oxidative modifications are implicated in the formation of antiphospholipid antibodies, which in turn may favour the oxidative imbalance by increasing the production of reactive oxidant species (ROS) or by a direct interaction with pro-oxidant/antioxidant enzymes. As a result of these processes, APS patients suffer from an oxidative imbalance that may contribute to the progression of the atherosclerotic process and to the onset of ischemic thrombotic complications. The aim of this review is to describe mechanisms implicated in the formation of ROS in APS patients and their involvement in the atherothrombotic process. We also provide an overview of potential therapeutic approaches to blunt oxidative stress and to prevent atherothrombotic complications in these patients.
\end{abstract}

Keywords: oxidative stress; thrombosis; antiphospholipid syndrome; antioxidant treatment

\section{Introduction}

In the early 1980s, the term antiphospholipid syndrome (APS) was coined to describe an autoimmune, multisystemic disorder characterized clinically by autoantibody-induced thrombophilia [1]. Today, APS is considered an autoimmune, thrombo-inflammatory disease characterized by vascular thrombosis in the setting of one or more antiphospholipid antibodies (aPLs) such as lupus anticoagulant (AL), anticardiolipin antibodies (aCL) and anti- $\beta 2$-glycoprotein1 antibodies (a $\beta 2 \mathrm{GPI}$ ) [2]. Beyond thrombosis, APS regularly manifests with other morbid features including thrombocytopenia, cardiac dysfunction [3], accelerated atherosclerosis, nephropathy, movement disorders, and cognitive decline $[4,5]$. This heterogeneous clinical presentation reflects the complex pathogenesis of APS, reinforc- 
ing the need for a deeper knowledge of mechanisms of aPL formation and of thrombotic complications, to allow a better-tailored, integrated, multidisciplinary approach.

It is known that the pathogenesis of APS consists of two phases: "the first hit and second hit". According to this theory, the "first hit" is represented by the presence of circulating aPL that destroy the integrity of the endothelium inducing a procoagulant phenotype. Nevertheless, aPL alone are not enough to cause thrombosis, which takes place only in the presence of a triggering factors (the "second hit"), which is usually represented by smoking, acute infections, oxidative stress or inflammation [6].

Growing evidence from cellular, animal, and human studies provides the direct role of oxidative stress in atherothrombosis. Therefore, oxidative stress, as a second hit, could have a fundamental role in the progression of the APS.

In this review we will examine the contribution of oxidative stress in the pathogenesis of APS and in particular in the setting of atherothrombosis. Specifically, we will describe (1) the role of oxidative stress in atherothrombosis development, (2) clinical and experimental evidence of increased oxidative stress in these patients and (3) antioxidant supplementation as a potential treatment.

\section{Mechanisms of Atherothrombosis in APS: The Role of Oxidative Stress}

The diagnosis of APS requires the concomitant presence of vascular thrombosis and/or pregnancy morbidity [7], in addition to persistent positivity to at least one of the aPL among LA, aCL and a 32 GPI. However, some patients may present noncriteria antibodies or unusual clinical manifestations [8,9]. Venous thromboembolism is the most common clinical presentation of the syndrome whereas arterial thrombosis is less frequent and mainly affects younger adults. The clinical spectrum of arterial thrombosis may extend from asymptomatic small ischemic lesions to fully ischemic stroke [10]. An observational study in 1000 APS patients from 13 European countries, that were followed prospectively for 10 years, showed that thrombotic events appeared in $16.6 \%$ during the first 5 years and $14.4 \%$ during the second 5 years. The most common events reported were strokes, transient ischaemic attacks, deep vein thrombosis and pulmonary embolism [11].

It's now well established that oxidative stress plays a major role in atherogenesis [12-14]. Oxidative stress is defined by an imbalance between reactive oxygen species (ROS) production and impaired detoxification by antioxidant enzymatic and nonenzymatic systems [15-17]. This imbalance characterizes several cardiovascular diseases (CVD) in which ROS are important mediators of endothelial damage leading to vascular inflammation and progression of the atherosclerotic plaque. The causal role of ROS in atherosclerosis and other cardiovascular diseases is supported by several animal models of oxidative stress.

Several mechanisms have been proposed as promoters of oxidative stress in APS patients (Figure 1).

Gergely et al. [18] verified, in patients with systemic lupus erythematosus, the hypothesis that the mitochondrial transmembrane potential and production of reactive oxygen intermediates (ROIs) mediate the imbalance of apoptosis which may significantly contribute to inflammation. In these patients, they found that mitochondrial transmembrane potential and ROI production were elevated compared to healthy subjects. Moreover, intracellular glutathione contents were diminished, and $\mathrm{H}_{2} \mathrm{O}_{2}$, a precursor of ROIs, increased mitochondrial transmembrane potential and caused apoptosis [18].

Another mechanism of oxidative stress can be related to the interactions between aCL antibodies and antioxidant enzymes in plasma, such as the paraoxonase-1 (PON1), which is an antioxidant enzyme linked to HDLs that prevents LDL oxidation. Indeed, in patients positive for aCL antibodies, the activity of PON1 was found to be dramatically decreased [19]. Charakida et al. [20] also confirmed the interactions between aCL antibodies and PON1. They showed that women with positive aPL antibodies have functional and structural arterial abnormalities that were associated with reduced activity of PON1. This implicates HDL and oxidative stress in the causal pathway for atherosclerosis in 
these patients. Moreover, in these patients, HDL has a "proatherogenic" phenotype by reducing nitric oxide bioavailability and impairing anti-inflammatory and antioxidant properties [20].

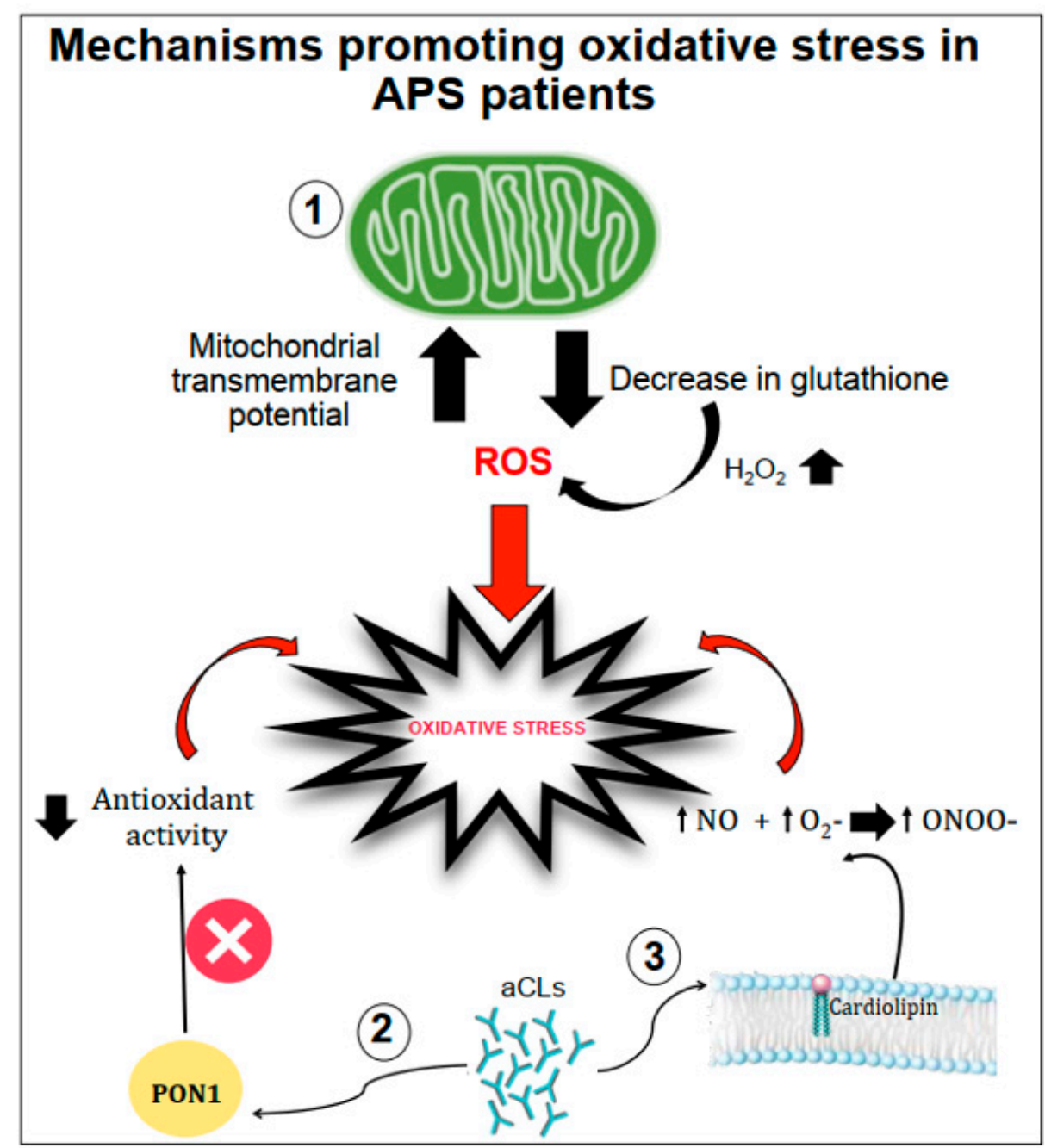

Figure 1. Schematic representation of mechanisms promoting oxidative stress in APS patients. Oxidative stress can be favoured by (1) the increase in the mitochondrial transmembrane potential and the decrease in intracellular glutathione contents; (2) the interactions between anticardiolipin antibodies (aCL) and the paraoxonase-1 (PON1) limiting its antioxidant properties; (3) aCL induction of nitric oxide $(\mathrm{NO})$ and superoxide $\left(\mathrm{O}_{2}^{-}\right)$production with increased levels of peroxynitrite $\left(\mathrm{ONOO}^{-}\right)$ a pro-oxidant molecule.

Finally, aCL seems to play an important role in promoting oxidative stress by inducing nitric oxide (NO) and superoxide production. This reaction favours enhanced production of plasma peroxynitrite, which is a powerful pro-oxidant substance. Indeed, in mice injected with aCL antibodies, there was an increase in serum nitrotyrosine suggesting that permanent pro-oxidant environment induces the activation of iNOS and results in longterm downregulation of iNOS expression and subsequent endothelial dysfunction [21].

When oxidative stress is established, it contributes significantly to the pathophysiology of APS by (1) inducing protein structural modification, and (2) interfering with nitric oxide metabolism (Figure 2). 


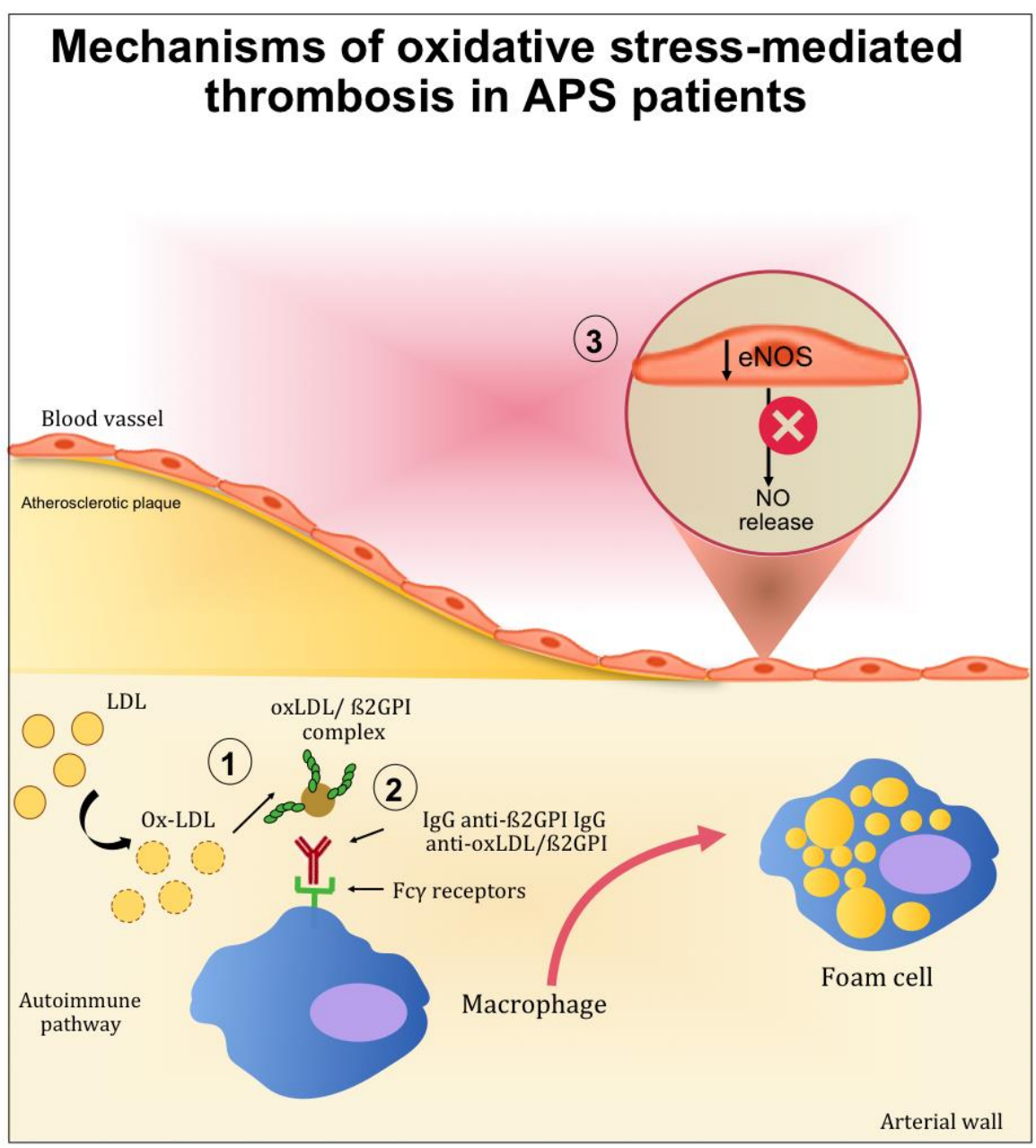

Figure 2. Mechanisms mediated by oxidative stress contributing to thrombotic complication in APS patients. (1) After oxidative modification, oxLDL binds $\beta 2$ GPI inside the arterial wall and further increases inflammation, oxidation, and cell activation. (2) Autoantibodies to this complex are produced resulting in circulating complexes (oxLDL/ $\beta 2 \mathrm{GPI} /$ antibody). In the presence of antioxLDL/ $\beta 2$ GPI antibodies, the uptake of oxLDL/ $\beta 2$ GPI complexes by macrophage is increased and may further accelerate the development of atherosclerosis. (3) The endothelial nitric oxide synthase (eNOS) in the endothelial cells is inactivated, reducing the nitric oxide (NO) bioavailability.

\subsection{The Role of Oxidative-Mediated Modifications}

Clinical and epidemiological studies suggested that the presence of anti- $\beta 2 \mathrm{GPI}$ antibodies confers a significant risk of thrombosis, morbidity and mortality in young adults [22]. For this reason, anti- $\beta 2 \mathrm{GPI}$ antibodies have been widely investigated to better understand the pathophysiology of APS and its complications.

$\beta 2 \mathrm{GPI}$ is a $50 \mathrm{kDa}$ protein synthesized as a single polypeptide chain. It is mainly produced in the liver and may be detected in the blood at a concentration of $200 \mu \mathrm{g} / \mathrm{mL}$. [23]. $\beta 2 \mathrm{GPI}$ has a role in coagulation, fibrinolysis, angiogenesis, and apoptosis [24]. Oxidation and nitrosylation of redox-sensitive cysteine residues are characteristic post-translational modifications of $\beta 2$ GPI occurring under conditions of increased oxidative or nitrosative stress. In particular, modifications of the sulfhydryl group $(\mathrm{SH})$ alter the function of proteins containing cysteines in their catalytic domain or as interface residues of interacting proteins. ROS readily react with cysteine residues, especially redox-active cysteines, to form reversible or irreversible oxidized forms.

S-nitrosylation refers to a chemical reaction that occurs spontaneously or enzymatically in the presence of high $\mathrm{NO}$ concentrations. As a covalent post-translational modification on the cysteine thiol residue, s-nitrosylation has emerged as an important mechanism for 
functional regulation of most or all main classes of protein and intracellular processes [25]. These post-translational modifications directly affect the function of $\beta 2 \mathrm{GPI}$ and also confer an increase in the immunogenicity of $\beta 2$ GPI. In particular, the oxidation of $\beta 2$ GPI may increase the immunogenicity of the molecule by (1) increasing the affinity of anti- $\beta 2 \mathrm{GPI}$ antibodies to oxidised $\beta 2 \mathrm{GPI}$; (2) causing immature monocyte-derived dendritic cells to mature that secret interleukin (IL)-12, IL-1, IL-6, IL-8, tumour necrosis factor- $\alpha$ and IL-10; (3) breaking immune tolerance [26].

The contribution of ROS to the development of APS has been studied in the context of lipid peroxidation and the formation of oxidized LDL (oxLDL)/ $\beta 2$ GPI complexes. Indeed, patients with systemic autoimmune diseases displayed increased lipid peroxidation and oxLDL production $[27,28]$. After oxidative modification, electrostatic forces initially mediate the bind between oxLDL and $\beta 2$ GPI. After this initial interaction, more stable complexes (non-dissociable) are formed and stabilized by covalent interactions. These complexes are both proatherogenic and immunogenic. Indeed, the binding of $\beta 2 \mathrm{GPI}$ to oxLDL may occur inside the intima microenvironment of the arterial wall and further increase inflammation, oxidation, cell activation and macrophage uptake of oxLDL/ $\beta 2 \mathrm{GPI}$ complexes [29]. Moreover, patients with SLE and APS produce autoantibodies to this complex [30], and the resulting circulating immune complexes (oxLDL/ $\beta 2 \mathrm{GPI} /$ antibody) may further accelerate the development of atherosclerosis. This was demonstrated in vitro by the increased uptake of oxLDL/ $\beta 2$ GPI complexes by macrophage in the presence of antioxLDL/ $\beta 2$ GPI antibodies [31,32]. These results provide an explanation for the accelerated development of atherosclerosis in autoimmune patients.

\subsection{Role of Oxidative Stress in Nitric Oxide Metabolism}

Among the mechanisms potentially implicated in oxidative stress-mediated atherothrombotic complications in APS, the inactivation of endothelial nitric oxide synthase (eNOS) is one of the most studied. eNOS is the predominant NOS isoform in the vasculature and is responsible for most of the nitric oxide (NO) produced in this tissue. NO is a short-lived gas molecule that is responsible for different biological actions in multiple tissues and cell types, and is synthesized by eNOS to preserve vascular homeostasis [33]. Moreover, it exerts an atheroprotective function, and it inhibits blood clots and platelets adhesion to the endothelium [34].

A hypothetical connection between APS and alterations in the NO bioavailability has been evaluated in several studies performed both in mice and humans [35-38]. The evidence resulting from these studies showed a direct connection between the altered production of NO and APS pathogenesis.

In patients with aPL, a negative correlation was found between urinary NO metabolites (NOx) and IgG anticardiolipin, suggesting that aPL can negatively affect NO physiological activities [39].

In mice, the injections of polyclonal aPL and $\beta 2$ GPI monoclonal antibodies isolated from human patients can reduce the plasma concentration of NO metabolites. Moreover, the injection of aPL suppressed eNOS-mediated vascular relaxation by acetylcholine. Finally, in mice lacking eNOS, the increase in leukocyte adhesion to vascular endothelium and thrombus formation induced by aPL was not observed [36].

In vitro studies carried out by Ramesh et al. showed the impact of aPL in endothelial cells. In mice, aPL produced an increase of monocyte adhesion to endothelial cells, which is a mechanism directly related to atherosclerosis [36]. The same authors examined the role of $\beta 2$ GPI in aPL antagonism to eNOS by experiments that alternately included and excluded $\beta 2$ GPI from the surface of endothelial cells. When these cells were deprived of $\beta 2 \mathrm{GPI}$, aPL did not cause eNOS inhibition, indicating that $\beta 2 \mathrm{GPI}$ is required for aPL full functioning [36-38].

\section{Oxidative Stress in APS: Clinical and Experimental Studies}

Several clinical studies evaluated oxidative stress biomarkers in APS patients (Table 1). 
Table 1. Clinical, experimental, and in vitro studies describing changes of biomarkers of oxidative stress in APS patients.

\begin{tabular}{|c|c|c|c|}
\hline \multicolumn{4}{|c|}{ HUMAN STUDIES } \\
\hline Author/(Year)/[Reference] & Study Type (Setting) & Markers of Oxidative Stress & Main Results vs. Controls \\
\hline Lambert et al., (2000) [19] & $\begin{array}{c}\mathrm{n}=56 \text { APS patients } \\
\mathrm{n}=71 \mathrm{HS}\end{array}$ & $\begin{array}{c}\text { PON1 } \\
\text { MDA-LDL }\end{array}$ & $\begin{array}{c}\downarrow \text { PON1 } \\
\uparrow \text { MDA-LDL }\end{array}$ \\
\hline Delgado Alves et al., (2002) [40] & $\begin{array}{l}\text { Cross-sectional study } \\
\mathrm{n}=32 \text { SLE } \\
\mathrm{n}=36 \text { with PAPS } \\
\mathrm{n}=20 \text { controls }\end{array}$ & $\begin{array}{l}\text { HDL cholesterol } \\
\text { PON activity } \\
\text { TAC }\end{array}$ & $\begin{array}{c}\downarrow \text { HDL } \\
\uparrow \text { anti-HDL antibodies } \\
\downarrow \text { PON activity } \\
\downarrow \text { TAC }\end{array}$ \\
\hline Ferro et al., (2003) [41] & $\begin{array}{c}\mathrm{n}=13 \text { APL patients } \\
\mathrm{n}=11 \text { negative APL patients }\end{array}$ & Isoprostane & $\uparrow 8$-isoprostane \\
\hline Matsuura et al., (2006) [42] & $\begin{array}{c}\mathrm{n}=93 \text { APS patients } \\
\mathrm{n}=161 \mathrm{HS}\end{array}$ & oxLDL/beta2GPI & $\uparrow$ oxLDL/beta2GPI \\
\hline Sciascia et al., (2012) [43] & $\begin{array}{c}\mathrm{n}=45 \text { APS patients } \\
\mathrm{n}=75 \mathrm{HS}\end{array}$ & Isoprostanes & $\begin{array}{c}\uparrow 8 \text { 8-isoprostane } \\
\uparrow \text { Prostaglandin E2 (PGE) }\end{array}$ \\
\hline Perez-Sanchez et al., (2015) [44] & $\begin{array}{c}\mathrm{n}=126 \text { APS patients } \\
\mathrm{n}=61 \mathrm{HS}\end{array}$ & $\begin{array}{l}\text { TAC } \\
\text { MnSOD } \\
\text { Catalase } \\
\text { GPx }\end{array}$ & $\begin{aligned} & \downarrow \text { TAC } \\
\uparrow & \text { MnSOD } \\
\uparrow & \text { Catalase } \\
& \downarrow \text { GPx }\end{aligned}$ \\
\hline Stanisavljevic et al., (2016) [45] & $\begin{array}{l}\text { Cross-sectional case-control } \\
\qquad \begin{array}{c}n=140 \text { APS patients } \\
n=40 \mathrm{HS}\end{array}\end{array}$ & $\begin{array}{l}\mathrm{LOOH} \\
\mathrm{AOPP} \\
\mathrm{tSHG} \\
\text { PON1 }\end{array}$ & $\begin{array}{l}\leftrightarrow \mathrm{LOOH} \\
\uparrow \mathrm{AOPP} \\
\downarrow \mathrm{tSHG} \\
\downarrow \mathrm{PON} 1\end{array}$ \\
\hline Lai et al., (2015) [46] & $\begin{array}{c}\mathrm{n}=12 \text { APS patients } \\
\mathrm{n}=54 \mathrm{HS}\end{array}$ & $\begin{array}{c}\text { mitochondrial mass } \\
\mathrm{O}_{2}^{-} \text {production } \\
\text { mTOR and FoxP3 expression }\end{array}$ & $\begin{array}{l}\uparrow \text { mitochondrial mass } \\
\uparrow \mathrm{O}_{2}^{-} \text {production } \\
\leftrightarrow \text { mTOR expression } \\
\downarrow \text { FoxP3 expression }\end{array}$ \\
\hline Ibrahim (2017) [47] & $\begin{array}{c}\mathrm{n}=75 \text { APS patients } \\
\mathrm{n}=120 \mathrm{HS}\end{array}$ & polymorphisms of the PON1 & $\leftrightarrow$ PON1 polymorphisms \\
\hline Nojima et al., (2020) [48] & $\begin{array}{c}\mathrm{n}=58 \text { APS patients } \\
\mathrm{n}=312 \mathrm{HS}\end{array}$ & OSI & $\uparrow$ OSI \\
\hline \multicolumn{4}{|c|}{ EXPERIMENTAL STUDIES } \\
\hline Delgado Alves et al., (2005) [49] & $\begin{array}{l}\text { mice with SCID+ } \\
\text { aCL and anti-a } \beta 2-G P I \\
\text { monoclonal antibodies }\end{array}$ & $\begin{array}{l}\text { PON activity } \\
\text { TAC }\end{array}$ & $\begin{array}{l}\downarrow \text { PON activity } \\
\downarrow \downarrow \text { TAC }\end{array}$ \\
\hline Benhamou et al., (2015) [50] & APS mice & $\begin{array}{l}\text { gp91phox mRNA } \\
\text { GSH/GSSH ratio }\end{array}$ & $\begin{array}{c}\uparrow \text { gp91phox mRNA } \\
\uparrow \text { left ventricular GSH/GSSH }\end{array}$ \\
\hline Ding et al., (2015) [51] & $\begin{array}{c}\text { APS mice } \\
\text { wild-type mice }\end{array}$ & p47phox & $\begin{array}{c}\uparrow \text { p } 47 \text { phox mRNA } \\
\uparrow \text { p47phox phosphorylation }\end{array}$ \\
\hline \multicolumn{4}{|c|}{ IN VITRO STUDIES } \\
\hline Ferro et al., (2003) [41] & $\begin{array}{l}\text { Human monocytes from (HS) } \\
\text { and } \\
\text { anti- } \beta_{2} \mathrm{GP}_{1} \text { antibodies }(50,100 \text {, } \\
200 \mu \mathrm{g} / \mathrm{mL})\end{array}$ & $\mathrm{O}_{2}^{-}$production & $\uparrow \mathrm{O}_{2}^{-}$production \\
\hline Simoncini et al., (2005) [52] & $\begin{array}{c}\text { HUVEC and } \\
\text { IgG (IgG-APS) from } \\
12 \text { APS patients }\end{array}$ & ROS production & $\begin{array}{c}\uparrow \text { ROS production } \\
\text { MAP kinases pathway: } \\
\uparrow \text { p38 phosphorylation } \\
\uparrow \text { ATF-2 }\end{array}$ \\
\hline
\end{tabular}

Abbreviations: healthy subjects (HS); Human umbilical vein endothelial cells (HUVEC); Mitogen-activated protein (MAP) kinases; activating transcription factor-2 (ATF-2); Oxidized low-density lipoprotein (oxLDL); b2-glycoprotein I (2GPI); prostaglandin E2 (PGE); Manganese-SOD, total antioxidant capacity (TAC); manganese-superoxide dismutase (MnSOD); glutathione peroxidase (GPx); lipid hydroperoxydes (LOOH); advanced oxidation protein products (AOPP); total sulfhydryl groups (tSHG); paraoxonase 1 activity (PON1); oxidation stress index (OSI); severe combined immunodeficiency (SCID); anticardiolipin (aCL); Total antioxidant capacity (TAC); $\uparrow$ increase; $\downarrow$ decrease; $\leftrightarrow$ no changes.

aPLs have been demonstrated to induce an increased expression of molecules able to produce an expanded oxidative status in plasma, as demonstrated by high levels of prostaglandin F2-isoprostanes in APS patients. F2-isoprostanes are arachidonic acid products formed on membrane phospholipids by the action of ROS. As F2-isoprostanes are characterized by stability and specificity for lipid peroxidation, they represent a reliable 
marker for quantitative measurement of lipid peroxidation oxidative stress in vivo and prediction of cardiovascular events [53,54]. Specifically, a study conducted on 45 APS patients found higher values of 8-isoprostanes in the APS group than in the other groups. Moreover, APS patients with enhanced inflammation and oxidative stress recorded more thrombotic events compared to control group (69\% vs. $6.5 \%)$. Similar results were showed by another study that investigates the relationship between oxidative stress and monocyte tissue factor (TF) expression in a cross-sectional comparison of aPL-positive and aPL-negative patients [41]. In fact, in these patients, an upregulation of monocyte TF expression was associated with thrombosis [55]. The results showed that compared with aPL-negative subjects, in aPL-positive patients higher values of isoprostanes and monocyte TF antigen and activity were observed [41].

PON1 is a hydrolytic enzyme with wide range of substrates, and a capability to protect against lipid oxidation. There is a considerable in vitro and in vivo data that prove the beneficial effects of PON1 in several atherosclerosis-related processes [56].

In an observational study, among 56 patients with APS, 37 presented arterial thrombosis, 16 presented venous thrombosis and all showed malondialdehyde-modified LDL (MDA-LDL) at significantly higher levels than controls. Furthermore, basal serum of PON1 activity was dramatically decreased in a subgroup of patients in comparison with the controls [19]. These results suggest that PON1 abnormalities that play a role in the APS might be associated with a higher risk of arterial thrombosis. Genetic analysis confirmed the role of PON1 in APS. In fact, PON1 L55M polymorphism resulted in an association with APS [47].

Consistently with these results, a cross-sectional study showed that PON1 is reduced in 36 patients with primary APS compared with 20 healthy subjects (HS) [40]. Additionally, the total antioxidant capacity (TAC), which quantifies the overall antioxidant defence of plasma, analysed in patients with primary APS did not differ significantly from levels in the control group, but correlated positively with PON activity [40].

Chronic, autoimmune, vascular inflammation together with decreased PON activity may contribute to oxidative stress, LDL modification (oxLDL) and oxLDL/2GPI complex formation that reflect the oxidative stress degree. Matsuura et al. revealed that serum levels of IgG anti-oxLDL/2GPI antibodies were significantly higher in systemic lupus erythematosus (SLE) patients with APS compared to SLE controls without APS. In addition, high concentrations of these IgG antibodies were observed in APS patients with a history of arterial thrombosis. Therefore, the presence of circulating oxLDL/2GPI complexes and IgG antibodies to these complexes indicates significant vascular damage and oxidative stress as well as a significant role in autoimmune-mediated atherothrombosis [42].

A cross-sectional case-control clinical study, including a total of 180 patients with primary and secondary APS and a control group, investigated several oxidative stress markers of endothelial damage measured by flow-mediated dilation (FMD). Biomarkers of oxidative stress, lipid hydroperoxydes ( $\mathrm{LOOH}$ ), advanced oxidation protein products (AOPP), total sulfhydryl groups (tSHG), and PON1 activity resulted altered in APS patients [45].

In addition to the evidence from human models, some studies on murine models supported that enhanced oxidative stress occurs in APS and the role of oxidant/antioxidant balance.

Severe combined immunodeficiency (SCID) mice were injected with Hybridomas producing human and murine aCL antibodies and $\beta 2 \mathrm{GPI}$ monoclonal antibodies. Results showed that PON1 activity, NO levels, and expression of total antioxidant capacity (TAC) were reduced. Conversely, peroxynitrite and superoxide concentration in plasma were increased. These data confirm that aCL antibodies are associated with the decreased PON activity and reduced endothelial function that may occur in the APS [49].

At the molecular level, it has been demonstrated that in the liver of the APS mouse model, both mRNA and protein expression of 47phox, a protein involved in the upregulation of nicotinamide adenine dinucleotide phosphate (NADPH) oxidase activity, were increased compared with the control group [51]. As NADPH oxidase is the main source 
of ROS [57], the results suggest that NADPH oxidase-mediated oxidative stress leads to endothelial cell injury in APS.

The studies described so far analyse the oxidative stress at plasmatic levels. PerezSanchez et al. studied oxidative stress at the cellular level by analysing biomarkers in circulating leucocytes from APS patients. Higher peroxide production, the nuclear abundance of Nrf2, antioxidant enzymatic activity, decreased intracellular glutathione, and altered mitochondrial membrane potential were found in monocytes and neutrophils from APS patients compared to healthy subjects [58]. Specifically, ROS production was markedly increased in monocytes and neutrophils of APS patients compared with healthy donors, as was the expression of Nrf2, the main regulator of antioxidant genes. Moreover, intracellular reduced GSH was significantly decreased in both cell types and the activities of catalase (CAT) and glutathione peroxidase (GPx) resulted in being strongly reduced. Furthermore, a significant systemic reduction of total antioxidant capacity (TAC) in plasma from APS patients was found compared to healthy donors, and might indicate a reduced ability to counteract ROS production and oxidative damage [58].

According to the results of these studies, showing that oxidative stress is directly involved in the pathophysiology of atherothrombosis in APS, the evaluation of oxidative stress biomarkers could be used as serologic indicators to assess the APS patient's risk for vascular complications. Moreover, vascular, preventive strategies and more targeted therapeutic interventions should be developed.

\section{Antioxidant Treatment in APS Patients: The State of the Art}

Common treatments for APS are long-term anticoagulation with vitamin K antagonists and antiplatelet drugs. To reinforce the effects of these therapies and to fight the effects of oxidative stress in APS, several potential new therapeutic approaches are under investigation. Strategies to inhibit oxidative stress involve drugs such as dabigatran and statins that, with different molecular mechanisms, can reduce vascular oxidative stress and inflammation and improve endothelial function.

A potential new therapeutic strategy should be represented by natural molecules such as vitamins, CoQ10, and omega-3 polyunsaturated fatty acid (n-3 PUFA) (Table 2).

Table 2. Main characteristics and main results of supplementation studies with antioxidants in patients with APS, experimental model of APS and in vitro studies.

\begin{tabular}{|c|c|c|c|}
\hline \multicolumn{4}{|c|}{ INTERVENTION STUDIES } \\
\hline \multicolumn{4}{|c|}{ HUMAN STUDIES } \\
\hline Author/(Year)/[Reference] & Study Type (Setting) & Type of Intervention/Doses & Main Results \\
\hline Rossi et al., (1993) [59] & $\begin{array}{l}\text { Patients with PAPS associated } \\
\text { with recurrent miscarriage } \\
\qquad \mathrm{n}=22\end{array}$ & EPA and DHA (5.1 g) & $\begin{array}{c}\text { Fish oil prevents recurrent miscarriage in } \\
\text { persistent APS }\end{array}$ \\
\hline Carta et al., (2005) [60] & $\begin{array}{c}\text { A prospective study } \\
\text { Patients with positive } \\
\text { antiphospholipid antibodies } \\
\mathrm{n}=30\end{array}$ & $\begin{array}{l}\text { Fish oil derivates } \\
\text { vs. } \\
\text { low dose aspirin }\end{array}$ & $\begin{array}{l}\text { No significant differences in adverse } \\
\text { pregnancy outcome after fish oil derivates. }\end{array}$ \\
\hline Felau et al., (2018) [61] & $\begin{array}{c}\text { Randomized double-blind } \\
\text { placebo-controlled trial } \\
\text { Women with primary APS } \\
n=22\end{array}$ & $\begin{array}{c}\text { EPA (1.8 g) and DHA }(1.3 \mathrm{~g}) \\
16 \text { weeks }\end{array}$ & $\begin{array}{c}\uparrow \text { endothelial function } \\
\downarrow \text { circulating levels of interleukin-10 } \\
\quad \text { and TNF } \\
\leftrightarrow \text { E- selectin, vascular adhesion } \\
\text { molecule-1, and fibrinogen levels }\end{array}$ \\
\hline Ferro et al., (2003) [41] & $\begin{array}{l}\text { Randomized clinical trial } \\
\text { APL positive patients } \\
n=11\end{array}$ & $\begin{array}{c}\text { Vitamin E (900 IU day) } \\
\text { Vitamin C (2000 mg day) } \\
6 \text { weeks }\end{array}$ & $\begin{array}{c}\downarrow \text { Isoprostanes } \\
\downarrow \text { Monocyte TF antigen }\end{array}$ \\
\hline
\end{tabular}


Table 2. Cont.

\begin{tabular}{|c|c|c|c|}
\hline \multicolumn{4}{|c|}{ INTERVENTION STUDIES } \\
\hline \multicolumn{4}{|c|}{ HUMAN STUDIES } \\
\hline Author/(Year)/[Reference] & Study Type (Setting) & Type of Intervention/Doses & Main Results \\
\hline Stopa et al., (2017) [62] & $\begin{array}{l}\text { Clinical trial } \\
\text { Patients with persistently elevated } \\
\text { anti-phospholipid antibodies } \\
n=6\end{array}$ & $\begin{array}{l}\text { Isoquercetin (1000 mg) } \\
\qquad 4 \mathrm{~h}\end{array}$ & $\begin{array}{c}\downarrow \text { thrombin generation (decrease of } 63.6 \% \text { ) } \\
\downarrow \text { platelet factor Va generation }\end{array}$ \\
\hline $\begin{array}{l}\text { Perez-Sanchez et al., } \\
\text { (2017) [63] }\end{array}$ & $\begin{array}{l}\text { Prospective, randomized, } \\
\text { crossover, placebo-controlled trial } \\
\qquad \mathrm{n}=36\end{array}$ & $\begin{array}{l}\mathrm{Q}_{\text {red }}(200 \mathrm{mg} / \mathrm{d}) \\
\text { vs. placebo } \\
1 \text { month }\end{array}$ & $\begin{array}{c}\uparrow \text { endothelial function } \\
\downarrow \text { monocyte expression of prothrombotic } \\
\text { and proinflammatory mediators } \\
\downarrow \text { peroxides }\end{array}$ \\
\hline \multicolumn{4}{|c|}{ EXPERIMENTAL STUDIES } \\
\hline Maalouly et al., (2017) [64] & $\begin{array}{l}\text { Murine experimental models of } \\
\text { antiphospholipid syndrome: } \\
\text { BALB/c mice immunized with } \\
\text { beta-2-glycoprotein I }\end{array}$ & $\begin{array}{l}\text { Omega- } 3 \text { fatty acids }(0.5 \mathrm{~g} / \mathrm{kg}) \\
\text { curcumin }(200 \mathrm{mg} / \mathrm{kg}) \\
3 \text { months in addition to the } \\
\text { treatment with enoxaparin } \\
(1 \mathrm{mg} / \mathrm{kg})\end{array}$ & $\downarrow$ mortality \\
\hline Ramadan et al., (2021) [65] & $\begin{array}{l}\text { Murine experimental models of } \\
\text { antiphospholipid syndrome: } \\
\text { esiquimod-induced } \\
\text { (R848-induced) lupus }\end{array}$ & $\begin{array}{l}\text { 6-gingerol }(20 \mathrm{mg} / \mathrm{kg} \\
\text { intraperitoneal injection }) \\
3 \text { times per week }\end{array}$ & $\begin{array}{c}\downarrow \text { NETs release } \\
\downarrow \text { Anti-dsDNA, anti- } \beta 2 \text { GPI, and total IgG } \\
\downarrow \text { thrombus length and weight }\end{array}$ \\
\hline \multicolumn{4}{|c|}{ IN VITRO STUDIES } \\
\hline Author/(year)/[reference] & Types of cells & $\begin{array}{c}\text { Type of antioxidant's } \\
\text { treatment }\end{array}$ & Main results \\
\hline Ferro et al., (2003) [41] & $\begin{array}{l}\text { Human healthy monocytes } \\
\text { treated with polyclonal } \\
\text { anti-b2GP1 antibodies }\end{array}$ & $\begin{array}{l}\text { Vitamin E concentrations } \\
\qquad(50,100 \mu \mathrm{M})\end{array}$ & $\begin{array}{l}\downarrow \text { superoxide anion } \\
\downarrow \text { TF Ag and activity }\end{array}$ \\
\hline Wei et al., (2020) [66] & $\begin{array}{l}\text { HUVECs treated with } \\
\text { anticardiolipin antibody (aCL) }\end{array}$ & Hyperoside $(10,20,50 \mathrm{mM})$ & $\begin{array}{c}\downarrow \text { IL-1b, IL-8, TF, ICAM1, and VCAM1 } \\
\uparrow \text { autophagy } \\
\downarrow \text { mTOR/S6K } \\
\downarrow \text { TLR4/Myd88/NF-kB signalling } \\
\text { transduction pathways }\end{array}$ \\
\hline $\begin{array}{l}\text { Perez-Sanchez et al., } \\
\text { (2017) [63] }\end{array}$ & $\begin{array}{l}\text { Human healthy monocytes } \\
\text { treated with IgG-APS }\end{array}$ & CoQ10 & $\begin{array}{c}\downarrow \text { oxidative stress } \\
\qquad \text { TF } \\
\downarrow \text { VEGF } \\
\downarrow \text { Flt1 receptor }\end{array}$ \\
\hline Wang et al., (2014) [67] & $\begin{array}{l}\text { Human acute monocytic } \\
\text { leukaemia cell line treated with } \\
\text { anti- } \beta 2 \text { glycoprotein I } \\
(\mathrm{GPI}) / \beta 2 \mathrm{GPI} \text { complex }\end{array}$ & $\begin{array}{l}\text { Epigallocatechin-3-gallate } \\
\qquad(0-50 \mu \mathrm{g} / \mathrm{mL})\end{array}$ & $\begin{array}{l}\downarrow \text { TF expression } \\
\downarrow \downarrow \text { TF activity }\end{array}$ \\
\hline \multicolumn{4}{|c|}{$\begin{array}{l}\text { Legend: anticardiolipin (aCL); } \beta 2 \text {-glycoprotein I (2GPI); docosahexaenoic acid (DHA); eicosapentaenoic acid (EPA); fms-related tyrosine } \\
\text { kinase } 1 \text { (FLT1); glutathione peroxidase (GPx); human umbilical vein endothelial cells (HUVEC); intercellular adhesion molecule } 1 \text { (ICAM1); } \\
\text { myeloid differentiation factor } 88 \text { (Myd88); mechanistic target of rapamycin (mTOR); nuclear factor kappa-light-chain enhancer of activated } \\
\text { B cells (NF kB) primary antiphospholipid syndrome (PAPS); paraoxonase } 1 \text { activity (PON1); severe combined immunodeficiency (SCID); } \\
\text { tissue factor (TF); Toll-like receptor } 4 \text { (TLR4); tumour necrosis factor- } \alpha \text { (TNF- } \alpha \text { ); vascular cell adhesion molecule } 1 \text { (VCAM1); vascular } \\
\text { endothelial growth factor (VEGF); } \uparrow \text { increase; } \downarrow \text { decrease; } \leftrightarrow \text { no changes. }\end{array}$} \\
\hline
\end{tabular}

\subsection{Human Studies}

Even if there is convincing evidence showing that oxidative stress is directly involved in the pathophysiology of atherothrombosis in APS, very few studies have evaluated the potential effect of antioxidant supplementation in these patients.

One therapeutic approach could be represented by omega-3 polyunsaturated fatty acid (n-3 PUFA) supplementation, which has been shown to improve endothelial function in several diseases and could have a role also in APS. In a pilot study in 1993, 22 patients with persistent APS associated with recurrent miscarriage were treated with fish oil, equivalent to $5.1 \mathrm{~g}$ eicosapentaenoic acid (EPA) and docosahexaenoic acid (DHA) at a ratio of 1.5 EPA to DHA. The results showed that fish oil prevents recurrent miscarriage in persistent APS [59]. Different results were revealed by Carta et al. Patients with at least two consecutive spontaneous abortions and positive antiphospholipid antibodies on two occasions were 
assigned to treatment with low-dose aspirin or fish oil derivatives. Results showed that the treatment of women with recurrent pregnancy loss associated with APS syndrome with fish oil derivates or low-dose aspirin did not lead to significant differences with respect to pregnancy outcome and complications [60].

More recently, a clinical trial involving 22 adult women with primary APS randomized to receive placebo or n-3 PUFA (capsule, $1.8 \mathrm{~g}$ of EPA and $1.3 \mathrm{~g}$ of DHA). After 16 weeks of supplementation, the $\omega-3$ group showed significant increases in endothelial function estimated by reactive hyperaemia index (RHI) when compared with placebo. In addition, the $\omega-3$ group showed decreased circulating levels of interleukin-10 ( $-4 \mathrm{vs} .+45 \%)$ and tumour necrosis factor $(-13$ vs. $+0.3 \%)$ and a tendency toward a lower intercellular adhesion molecule-1 response ( +3 vs. $+48 \%$ ) after treatment when compared with placebo. Conversely, no changes were observed for E-selectin, vascular adhesion molecule 1, and fibrinogen levels [61].

The effect of combined antioxidant treatment with Vitamin E and Vitamin C was investigated by Ferro et al. [41]. Eleven APS-positive patients were randomly supplemented either with or without antioxidants (vitamin E at $900 \mathrm{IU} /$ day and vitamin C at $2000 \mathrm{mg} /$ day) for 6 weeks. APL-positive patients showed increased oxidative stress that induced an overexpression of monocyte tissue factor (TF), contributing to activate the clotting system. Results showed that patients who received antioxidant supplementation had a significant reduction in isoprostanes and monocyte TF antigen and activity [41].

Stopa et al. evaluated the effect of flavonoid quercetins in a cohort of patients with persistently elevated antiphospholipid antibodies. Quercetin-3-rutinoside is a small, potent inhibitor of protein disulphide isomerase (PDI) that plays a critical role in thrombus formation. Oral administration of $1.000 \mathrm{mg}$ isoquercetin decreased by $64 \%$ platelet-dependent thrombin generation in the antiphospholipid antibody cohort. Moreover, isoquercetin ingestion resulted in a decrease in the generation of platelet factor Va [62].

Finally, in a prospective, randomized, crossover, placebo-controlled trial, PerezSanchez et al. evaluated the short-term effects of in vivo ubiquinol, the reduced coenzyme $Q_{10}\left[Q_{\text {red }}\right]$, supplementation on biomarkers related to inflammation and thrombosis in APS. Thirty-six patients with APS were randomized to receive $Q_{\text {red }}(200 \mathrm{mg} / \mathrm{d})$ or placebo for 1 month. Results showed that $Q_{\text {red }}(1)$ improved endothelial function and decreased the expression of prothrombotic and proinflammatory mediators by monocyte, (2) inhibited phosphorylation of thrombosis-related protein kinases, and (3) decreased peroxides and percentage of monocytes with depolarized mitochondria. Moreover, $\mathrm{Q}_{\text {red }}$ significantly reduces the percentage of neutrophil extracellular traps released by activated neutrophils, and in monocytes it downregulates peroxides production, intracellular elastase, and myeloperoxidase expression [63].

\subsection{Experimental and In Vitro Studies}

Murine experimental models of antiphospholipid syndrome (eAPLS) were used to test the effect of Omega-3 fatty acids and curcumin on neurologic severity. BALB/c mice immunized with beta-2-glycoprotein I received omega- 3 fatty acids $(0.5 \mathrm{~g} / \mathrm{kg})$, and curcumin $(200 \mathrm{mg} / \mathrm{kg})$ for 3 months in addition to treatment with enoxaparin $(1 \mathrm{mg} / \mathrm{kg})$. The enoxaparin and omega- 3 fatty acids combination was correlated with a reduction in mortality, demonstrating an interesting therapeutic approach using omega-3 in eAPLS [64]. Another study evaluated the effect of 6-gingerol, one of the main functional compounds in the extract of ginger. The administration of antiphospholipid antibodies to mice increased thrombus length and weight, which returned to control levels upon administration of 6-gingerol ( $20 \mathrm{mg} / \mathrm{kg}$, three times per week). The mechanism hypostatized is dependent on NETs formation. Indeed, NETs contribute to APS pathophysiology as amplifiers of inflammation and thrombosis. Indeed, the aPL administration increased serum NET levels, which returned to baseline when mice were treated with 6-gingerol [65].

Other data are provided by in vitro experiments. Ferro et al. evaluated the effect of Vitamin E on TF and oxidative stress in human healthy monocytes. When cells were 
treated with polyclonal anti-b2GP1 antibodies, a dose-dependent increase in oxidative stress, as indicated by the increase in superoxide anion and TF Ag and activity production compared to monocytes stimulated with IgG of normal healthy subjects, was observed. The pretreatment with vitamin E concentrations $(50,100 \mu \mathrm{M})$ dose-dependently reduced superoxide anion and TF Ag and activity production [41].

Wei et al. evaluated the effect of hyperoside, which is a flavonoid glycoside compound mainly found in medicinal herbs, displaying antioxidative, anticancer, and antiinflammatory properties in many molecular pathways. Human umbilical vein endothelial cells (HUVECs) were treated with anticardiolipin antibody (aCL) to induce a vascular endothelial injury. When HUVECs were pretreated with hyperoside (10, 20, $50 \mathrm{mM})$ for $24 \mathrm{~h}$, the secretion of proinflammatory cytokines, such as IL-1b and IL-8, and endothelial adhesion cytokines such as TF, ICAM1, and VCAM1, was significantly reduced. Mechanistically, hyperoside activated autophagy and suppressed the mTOR/S6K and TLR4/Myd88/NF-k B signalling transduction pathways [66].

Perez-Sanchez et al. evaluated the effect CoQ10 on mitochondrial dysfunction. The preincubation of human healthy monocytes with CoQ10, followed by treatment with IgG-APS, significantly decreased oxidative stress and the percentage of cells with altered mitochondrial membrane potential, suggesting a positive effect on alterations in mitochondrial dynamics and metabolism. Moreover, CoQ10 reduced the expression of the thrombotic and proinflammatory markers such as $\mathrm{TF}$, vascular endothelial growth factor (VEGF) and its receptor Flt1, which were increased after the treatment with IgG-APS [58].

Finally, Wang et al. tested the effect of Epigallocatechin-3-gallate (EGCG), which is the major polyphenolic component of green tea, on blocking the effects of the anti$\beta 2$ glycoprotein I (GPI)/ $\beta 2$ GPI complex. This complex activates endothelial cells and monocytes promoting TF activity, increasing the risk of thrombosis, and enhancing the expression and secretion of proinflammatory cytokines. Human acute monocytic leukaemia cell line (THP-1) treated with anti- $\beta 2$ glycoprotein I (GPI)/ $\beta 2$ GPI complex displayed increased expression of TF and tumour necrosis factor- $\alpha$ (TNF- $\alpha)$. When the cells were pretreated with EGCG $(0-50 \mu \mathrm{g} / \mathrm{mL})$ before the stimulation with the anti- $\beta 2 \mathrm{GPI} / \beta 2 \mathrm{GPI}$ complex, TF expression and activity were significantly reduced [67].

\section{Conclusions and Future Perspective}

Oxidative stress is directly involved in the pathogenesis of atherothrombosis in APS patients. Several mechanisms have been proposed and have highlighted the role of aCL as a key promoter of oxidative stress and mitochondrial dysfunction. Oxidative stress, in turn, favours endothelial dysfunction, mainly associated with the alteration of NO metabolism, and stimulates a prothrombotic and proinflammatory status in APS patients.

Since the role of oxidative stress is well established, oxidative stress biomarkers should be used for thrombotic risk assessment in these patients and to plan antioxidant therapy for the reduction of thrombotic risk. In vitro studies are consistent in supporting a beneficial effect of treatment with antioxidants in reducing biomarkers of thrombosis. However, to date, there are little data on the administration of antioxidants in these patients, with no conclusive results. Therefore, further study with a more adequate methodology must be performed to assess the validity of antioxidant supplementation in patients with APS.

Author Contributions: Conceptualization and review process, C.N., S.B., V.C., R.C.; writing, C.N., S.B., V.C., R.C., SMiLe Group; figure and tables preparation, C.N., S.B., V.C., P.R., C.F., A.D.; review and editing of final manuscript, G.F., S.S., D.P., A.C., O.R.; supervision, R.C. All authors have read and agreed to the published version of the manuscript.

Funding: This research received no external funding.

Acknowledgments: SMiLe Group: Ballardini L, Benazzi B, Bricchi B, Corradi M, Duse A, Ferrara G, Feudo G, Luparo I, Marini L, Motta G, Occhipinti F, Rastelli L, Riccardi F, Scapin G, Scarpelli M, Testa M, Tricoci E, Venturini B, Vitale S, Vianiello A, Xhelilaj D, Zara F.

Conflicts of Interest: The authors declare no conflict of interest. 


\section{References}

1. Ruiz-Irastorza, G.; Crowther, M.; Branch, W.; Khamashta, M.A. Antiphospholipid syndrome. Lancet 2010, 376, 1498-1509. [CrossRef]

2. Willis, R.; Pierangeli, S.S. Pathophysiology of the antiphospholipid antibody syndrome. Autoimmun. Highlights 2011, 2, 35-52. [CrossRef]

3. Pastori, D.; Ames, P.R.J.; Triggiani, M.; Ciampa, A.; Cammisotto, V.; Carnevale, R.; Pignatelli, P.; Bucci, T. Antiphospholipid antibodies and heart failure with preserved ejection fraction. The multicenter athero-aps study. J. Clin. Med. 2021, 10, 3180. [CrossRef] [PubMed]

4. Abreu, M.M.; Danowski, A.; Wahl, D.G.; Amigo, M.C.; Tektonidou, M.; Pacheco, M.S.; Fleming, N.; Domingues, V.; Sciascia, S.; Lyra, J.O.; et al. The relevance of "non-criteria" clinical manifestations of antiphospholipid syndrome: 14th International Congress on Antiphospholipid Antibodies Technical Task Force Report on Antiphospholipid Syndrome Clinical Features. Autoimmun. Rev. 2015, 14, 401-414. [CrossRef]

5. Bucci, T.; Menichelli, D.; Pignatelli, P.; Triggiani, M.; Violi, F.; Pastori, D. Relationship of Antiphospholipid Antibodies to Risk of Dementia: A Systematic Review. J. Alzheimer's Dis. 2019, 69, 561-576. [CrossRef] [PubMed]

6. Meroni, P.L.; Borghi, M.O.; Raschi, E.; Tedesco, F. Pathogenesis of antiphospholipid syndrome: Understanding the antibodies. Nat. Rev. Rheumatol. 2011, 7, 330-339. [CrossRef] [PubMed]

7. De Jesús, G.R.; Benson, A.E.; Chighizola, C.B.; Sciascia, S.; Branch, D.W. 16th International Congress on Antiphospholipid Antibodies Task Force Report on Obstetric Antiphospholipid Syndrome. Lupus 2020, 29, 1601-1615. [CrossRef]

8. Pignatelli, P.; Ettorre, E.; Menichelli, D.; Pani, A.; Violi, F.; Pastori, D. Seronegative antiphospholipid syndrome: Refining the value of "non-criteria" antibodies for diagnosis and clinical management. Haematologica 2020, 105, 562-572. [CrossRef]

9. El Hasbani, G.; Taher, A.T.; Sciascia, S.; Uthman, I. Antiphospholipid syndrome: The need for new international classification criteria. Expert Rev. Clin. Immunol. 2021, 17, 385-394. [CrossRef]

10. Pastori, D.; Misasi, R.; Sorice, M.; Cribari, F.; Menichelli, D.; Violi, F.; Pignatelli, P. Multiple Arterial Thrombosis in Seronegative Antiphospholipid Syndrome: Need for New Diagnostic Criteria? Eur. J. Case Reports Intern. Med. 2019, 6, 1. [CrossRef]

11. Cervera, R.; Serrano, R.; Pons-Estel, G.J.; Ceberio-Hualde, L.; Shoenfeld, Y.; De Ramón, E.; Buonaiuto, V.; Jacobsen, S.; Zeher, M.M.; Tarr, T.; et al. Morbidity and mortality in the antiphospholipid syndrome during a 10-year period: A multicentre prospective study of 1000 patients. Ann. Rheum. Dis. 2015, 74, 1011-1018. [CrossRef] [PubMed]

12. Carnevale, R.; Pignatelli, P.; Lenti, L.; Buchetti, B.; Sanguigni, V.; Di Santo, S.; Violi, F. LDL are oxidatively modified by platelets via GP91(phox) and accumulate in human monocytes. FASEB J. 2007, 21, 927-934. [CrossRef]

13. Carnevale, R.; Bartimoccia, S.; Nocella, C.; Di Santo, S.; Loffredo, L.; Illuminati, G.; Lombardi, E.; Boz, V.; Del Ben, M.; De Marco, L.; et al. LDL oxidation by platelets propagates platelet activation via an oxidative stress-mediated mechanism. Atherosclerosis 2014, 237, 108-116. [CrossRef]

14. Violi, F.; Loffredo, L.; Carnevale, R.; Pignatelli, P.; Pastori, D. Atherothrombosis and Oxidative Stress: Mechanisms and Management in Elderly. Antioxid. Redox Signal. 2017, 27, 1083-1124. [CrossRef] [PubMed]

15. Conti, V.; Forte, M.; Corbi, G.; Russomanno, G.; Formisano, L.; Landolfi, A.; Izzo, V.; Filippelli, A.; Vecchione, C.; Carrizzo, A. Sirtuins: Possible Clinical Implications in Cardio and Cerebrovascular Diseases. Curr. Drug Targets 2016, 18, 473-484. [CrossRef] [PubMed]

16. Miceli, M.; Roma, E.; Rosa, P.; Feroci, M.; Loreto, M.A.; Tofani, D.; Gasperi, T. Synthesis of Benzofuran-2-one derivatives and evaluation of their antioxidant capacity by comparing DPPH assay and cyclic voltammetry. Molecules 2018, 23, 710. [CrossRef]

17. Nocella, C.; Cammisotto, V.; Pigozzi, F.; Borrione, P.; Fossati, C.; D’amico, A.; Cangemi, R.; Peruzzi, M.; Gobbi, G.; Ettorre, E.; et al. Impairment between Oxidant and Antioxidant Systems: Short- and Long-term Implications for Athletes' Health. Nutrients 2019, 11, 1353. [CrossRef]

18. Gergely, P.; Grossman, C.; Niland, B.; Puskas, F.; Neupane, H.; Allam, F.; Banki, K.; Phillips, P.E.; Perl, A. Mitochondrial hyperpolarization and ATP depletion in patients with systemic lupus erythematosus. Arthritis Rheum. 2002, 46, 175-190. [CrossRef]

19. Lambert, M.; Boullier, A.; Hachulla, E.; Fruchart, J.C.; Teissier, E.; Hatron, P.Y.; Duriez, P. Paraoxonase activity is dramatically decreased in patients positive for anticardiolipin antibodies. Lupus 2000, 9, 299-300. [CrossRef]

20. Charakida, M.; Besler, C.; Batuca, J.R.; Sangle, S.; Marques, S.; Sousa, M.; Wang, G.; Tousoulis, D.; Delgado Alves, J.; Loukogeorgakis, S.P.; et al. Vascular abnormalities, paraoxonase activity, and dysfunctional HDL in primary antiphospholipid syndrome. JAMA—J. Am. Med. Assoc. 2009, 302, 1210-1217. [CrossRef]

21. Alves, J.D.; Grima, B. Oxidative stress in systemic lupus erythematosus and antiphospholipid syndrome: A gateway to atherosclerosis. Curr. Rheumatol. Rep. 2003, 5, 383-390. [CrossRef] [PubMed]

22. Sciascia, S.; Baldovino, S.; Schreiber, K.; Solfietti, L.; Radin, M.; Cuadrado, M.J.; Menegatti, E.; Erkan, D.; Roccatello, D. Thrombotic risk assessment in antiphospholipid syndrome: The role of new antibody specificities and thrombin generation assay. Clin. Mol. Allergy 2016, 14, 6. [CrossRef]

23. Lozier, J.; Takahashi, N.; Putnam, F.W. Complete amino acid sequence of human plasma $\beta 2$-glycoprotein I. Proc. Natl. Acad. Sci. USA 1984, 81, 3640-3644. [CrossRef] [PubMed]

24. Nakagawa, H.; Yasuda, S.; Miyazaki, T. Novel Function of Beta 2 Glycoprotein I in Angiogenesis. Curr. Angiogenes. 2015, 3, 132-138. [CrossRef] 
25. Hess, D.T.; Matsumoto, A.; Kim, S.O.; Marshall, H.E.; Stamler, J.S. Protein S-nitrosylation: Purview and parameters. Nat. Rev. Mol. Cell Biol. 2005, 6, 150-166. [CrossRef] [PubMed]

26. Passam, F.H.; Giannakopoulos, B.; Mirarabshahi, P.; Krilis, S.A. Molecular pathophysiology of the antiphospholipid syndrome: The role of oxidative post-translational modification of beta 2 glycoprotein I. J. Thromb. Haemost. 2011, 9, 275-282. [CrossRef]

27. Morgan, P.E.; Sturgess, A.D.; Davies, M.J. Increased levels of serum protein oxidation and correlation with disease activity in systemic lupus erythematosus. Arthritis Rheum. 2005, 52, 2069-2079. [CrossRef] [PubMed]

28. Frostegård, J.; Svenungsson, E.; Wu, R.; Gunnarsson, I.; Lundberg, I.E.; Klareskog, L.; Hörkkö, S.; Witztum, J.L. Lipid peroxidation is enhanced in patients with systemic lupus erythematosus and is associated with arterial and renal disease manifestations. Arthritis Rheum. 2005, 52, 192-200. [CrossRef]

29. Matsuura, E.; Lopez, L. Autoimmune-mediated atherothrombosis. Lupus 2008, 17, 879-888. [CrossRef] [PubMed]

30. Kobayashi, K.; Kishi, M.; Atsumi, T.; Bertolaccini, M.L.; Makino, H.; Sakairi, N.; Yamamoto, I.; Yasuda, T.; Khamashta, M.A.; Hughes, G.R.V.; et al. Circulating oxidized LDL forms complexes with $\beta$ 2-glycoprotein I: Implication as an atherogenic autoantigen. J. Lipid Res. 2003, 44, 716-726. [CrossRef] [PubMed]

31. Hasunuma, Y.; Matsuura, E.; Makita, Z.; Katahira, T.; Nishi, S.; Koike, T. Involvement of beta2-glycoprotein I and anticardiolipin antibodies in oxidatively modified low-density lipoprotein uptake by macrophages. Clin. Exp. Immunol. 1997, 107, 569-573. [CrossRef] [PubMed]

32. Kobayashi, K.; Matsuura, E.; Liu, Q.; Furukawa, J.I.; Kaihara, K.; Inagaki, J.; Atsumi, T.; Sakairi, N.; Yasuda, T.; Voelker, D.R.; et al. A specific ligand for $\beta 2$-glycoprotein I mediates autoantibody-dependent uptake of oxidized low density lipoprotein by macrophages. J. Lipid Res. 2001, 42, 697-709. [CrossRef]

33. Förstermann, U.; Sessa, W.C. Nitric oxide synthases: Regulation and function. Eur. Heart J. 2012, 33, 829-837. [CrossRef] [PubMed]

34. Loscalzo, J. Jin Vascular nitric oxide: Formation and function. J. Blood Med. 2010, 1, 147. [CrossRef] [PubMed]

35. Ames, P.R.J.; Tommasino, C.; Alves, J.; Morrow, J.D.; Iannaccone, L.; Fossati, G.; Caruso, S.; Caccavo, F.; Brancaccio, V. Antioxidant susceptibility of pathogenic pathways in subjects with antiphospholipid antibodies: A pilot study. Lupus 2000, 9, 688-695. [CrossRef] [PubMed]

36. Ramesh, S.; Morrell, C.N.; Tarango, C.; Thomas, G.D.; Yuhanna, I.S.; Girardi, G.; Herz, J.; Urbanus, R.T.; De Groot, P.G.; Thorpe, P.E.; et al. Antiphospholipid antibodies promote leukocyte-endothelial cell adhesion and thrombosis in mice by antagonizing eNOS via $\beta 2$ GPI and apoER2. J. Clin. Investig. 2011, 121, 120-131. [CrossRef] [PubMed]

37. Urbanus, R.T.; Pennings, M.T.T.; Derksen, R.H.W.M.; de Groot, P.G. Platelet activation by dimeric $\beta 2$-glycoprotein I requires signaling via both glycoprotein $\mathrm{Ib} \alpha$ and apolipoprotein E receptor 2'. J. Thromb. Haemost. 2008, 6, 1405-1412. [CrossRef]

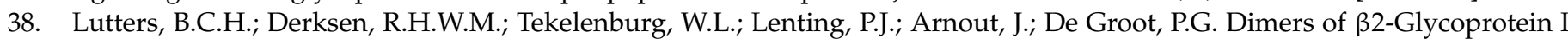
Increase Platelet Deposition to Collagen via Interaction with Phospholipids and the Apolipoprotein E Receptor 2'. J. Biol. Chem. 2003, 278, 33831-33838. [CrossRef]

39. Ames, P.R.J.; Batuca, J.R.; Ciampa, A.; Iannaccone, L.; Alves, J.D. Clinical relevance of nitric oxide metabolites and nitrative stress in thrombotic primary antiphospholipid syndrome. J. Rheumatol. 2010, 37, 2523-2530. [CrossRef] [PubMed]

40. Ramesh, S.; Morrell, C.N.; Tarango, C.; Thomas, G.D.; Yuhanna, I.S.; Girardi, G.; Herz, J.; Urbanus, R.T.; De Groot, P.G.; Thorpe, P.E.; et al. Antibodies to high-density lipoprotein and beta2-glycoprotein I are inversely correlated with paraoxonase activity in systemic lupus erythematosus and primary antiphospholipid syndrome. Arthritis Rheum. 2002, 46, 2686-2694. [CrossRef]

41. Ferro, D.; Saliola, M.; Meroni, P.L.; Valesini, G.; Caroselli, C.; Praticó, D.; Fitzgerald, G.A.; Shoenfeld, Y.; Violi, F. Enhanced monocyte expression of tissue factor by oxidative stress in patients with antiphospholipid antibodies: Effect of antioxidant treatment. J. Thromb. Haemost. 2003, 1, 523-531. [CrossRef]

42. Matsuura, E.; Kobayashi, K.; Hurley, B.L.; Lopez, L.R. Atherogenic oxidized low-density lipoprotein/ $\beta 2-$ glycoprotein I (oxLDL/ $\beta 2$ GPI) complexes in patients with systemic lupus erythematosus and antiphospholipid syndrome. Lupus 2006, 15, 478-483. [CrossRef]

43. Sciascia, S.; Roccatello, D.; Bertero, M.T.; Di Simone, D.; Cosseddu, D.; Vaccarino, A.; Bazzan, M.; Rossi, D.; Garcia-Fernandez, C.; Ceberio, L.; et al. 8-Isoprostane, prostaglandin E2, C-reactive protein and serum amyloid A as markers of inflammation and oxidative stress in antiphospholipid syndrome: A pilot study. Inflamm. Res. 2012, 61, 809-816. [CrossRef] [PubMed]

44. Perez-Sanchez, C.; Barbarroja, N.; Messineo, S.; Ruiz-Limon, P.; Rodriguez-Ariza, A.; Jimenez-Gomez, Y.; Khamashta, M.A.; Collantes-Estevez, E.; Cuadrado, M.J.; Aguirre, M.A.; et al. Gene profiling reveals specific molecular pathways in the pathogenesis of atherosclerosis and cardiovascular disease in antiphospholipid syndrome, systemic lupus erythematosus and antiphospholipid syndrome with lupus. Ann. Rheum. Dis. 2015, 74, 1441-1449. [CrossRef] [PubMed]

45. Stanisavljevic, N.; Stojanovich, L.; Marisavljevic, D.; Djokovic, A.; Dopsaj, V.; Kotur-Stevuljevic, J.; Martinovic, J.; Memon, L.; Radovanovic, S.; Todic, B.; et al. Lipid peroxidation as risk factor for endothelial dysfunction in antiphospholipid syndrome patients. Clin. Rheumatol. 2016, 35, 2485-2493. [CrossRef] [PubMed]

46. Lai, Z.-W.; Marchena-Mendez, I.; Perl, A. Oxidative stress and Treg depletion in lupus patients with anti-phospholipid syndrome. Clin. Immunol. 2015, 158, 148-152. [CrossRef]

47. Ibrahim, A.A.; El-Lebedy, D.; Ashmawy, I.; Hady, M.A. Association between paraoxonase-1 gene Q192R and L55M polymorphisms in systemic lupus erythematosus (SLE) and anti-phospholipid syndrome (APS) in a population from Cairo of Egypt. Clin. Rheumatol. 2017, 36, 1305-1310. [CrossRef] [PubMed] 
48. Nojima, J.; Kaneshige, R.; Motoki, Y.; Ieko, M. Increased oxidative stress may be a risk factor for thromboembolic complications in patients with antiphospholipid syndrome. Thromb. Res. 2020, 196, 52-53. [CrossRef]

49. Delgado Alves, J.; Mason, L.J.; Ames, P.R.J.; Chen, P.P.; Rauch, J.; Levine, J.S.; Subang, R.; Isenberg, D.A. Antiphospholipid antibodies are associated with enhanced oxidative stress, decreased plasma nitric oxide and paraoxonase activity in an experimental mouse model. Rheumatology 2005, 44, 1238-1244. [CrossRef] [PubMed]

50. Benhamou, Y.; Miranda, S.; Armengol, G.; Harouki, N.; Drouot, L.; Zahr, N.; Thuillez, C.; Boyer, O.; Levesque, H.; Joannides, R.; et al. Infliximab improves endothelial dysfunction in a mouse model of antiphospholipid syndrome: Role of reduced oxidative stress. Vascul. Pharmacol. 2015, 71, 93-101. [CrossRef]

51. Ding, X.; Yang, Z.; Han, Y.; Yu, H. Correlation of long-chain fatty acid oxidation with oxidative stress and inflammation in pre-eclampsia-like mouse models. Placenta 2015, 36, 1442-1449. [CrossRef]

52. Simoncini, S. Role of reactive oxygen species and p38 MAPK in the induction of the pro-adhesive endothelial state mediated by IgG from patients with anti-phospholipid syndrome. Int. Immunol. 2005, 17, 489-500. [CrossRef]

53. Milne, G.L.; Yin, H.; Hardy, K.D.; Davies, S.S.; Roberts, L.J. Isoprostane generation and function. Chem. Rev. 2011, 111, 5973-5996. [CrossRef]

54. Pignatelli, P.; Pastori, D.; Carnevale, R.; Farcomeni, A.; Cangemi, R.; Nocella, C.; Bartimoccia, S.; Vicario, T.; Saliola, M.; Lip, G.Y.H.; et al. Serum NOX2 and urinary isoprostanes predict vascular events in patients with atrial fibrillation. Thromb. Haemost. 2015, 113, 617-624. [CrossRef] [PubMed]

55. Amengual, O.; Atsumi, T.; Khamashta, M.A.; Hughes, G.R. The role of the tissue factor pathway in the hypercoagulable state in patients with the antiphospholipid syndrome. Thromb. Haemost. 1998, 79, 276-281. [CrossRef]

56. Litvinov, D.; Mahini, H.; Garelnabi, M. Antioxidant and anti-inflammatory role of paraoxonase 1: Implication in arteriosclerosis diseases. N. Am. J. Med. Sci. 2012, 4, 523-532. [CrossRef] [PubMed]

57. Manea, A. NADPH oxidase-derived reactive oxygen species: Involvement in vascular physiology and pathology. Cell Tissue Res. 2010, 342, 325-339. [CrossRef]

58. Perez-Sanchez, C.; Ruiz-Limon, P.; Aguirre, M.A.; Bertolaccini, M.L.; Khamashta, M.A.; Rodriguez-Ariza, A.; Segui, P.; CollantesEstevez, E.; Barbarroja, N.; Khraiwesh, H.; et al. Mitochondrial dysfunction in antiphospholipid syndrome: Implications in the pathogenesis of the disease and effects of coenzyme Q 10 treatment. Blood 2012, 119, 5859-5870. [CrossRef]

59. Rossi, E.; Costa, M. Fish Oil Derivatives as a Prophylaxis of Recurrent Miscarriage Associated with Antiphospholipid Antibodies (APL): A Pilot Study. Lupus 1993, 2, 319-323. [CrossRef]

60. Carta, G.; Iovenitti, P.; Falciglia, K. Recurrent miscarriage associated with antiphospholipid antibodies: Prophylactic treatment with low-dose aspirin and fish oil derivates. Clin. Exp. Obstet. Gynecol. 2005, 32, 49-51. [PubMed]

61. Felau, S.M.; Sales, L.P.; Solis, M.Y.; Hayashi, A.P.; Roschel, H.; Sá-Pinto, A.L.; De Andrade, D.C.O.; Katayama, K.Y.; Irigoyen, M.C.; Consolim-Colombo, F; et al. Omega-3 fatty acid supplementation improves endothelial function in primary antiphospholipid syndrome: A small-scale randomized double-blind placebo-controlled trial. Front. Immunol. 2018, 9, 336. [CrossRef]

62. Stopa, J.D.; Neuberg, D.; Puligandla, M.; Furie, B.; Flaumenhaft, R.; Zwicker, J.I. Protein disulfide isomerase inhibition blocks thrombin generation in humans by interfering with platelet factor V activation. JCI Insight 2017, 2. [CrossRef] [PubMed]

63. Pérez-Sánchez, C.; Aguirre, M.Á.; Ruiz-Limón, P.; Ábalos-Aguilera, M.C.; Jiménez-Gómez, Y.; Arias-de la Rosa, I.; RodriguezAriza, A.; Fernández-del Río, L.; González-Reyes, J.A.; Segui, P.; et al. Ubiquinol Effects on Antiphospholipid Syndrome Prothrombotic Profile. Arterioscler. Thromb. Vasc. Biol. 2017, 37, 1923-1932. [CrossRef]

64. Maalouly, G.; Ward, C.; Smayra, V.; Saliba, Y.; Aftimos, G.; Haddad, F.; Farès, N. Fish oil attenuates neurologic severity of antiphospholipid syndrome in a mice experimental model. Nutr. Neurosci. 2017, 20, 563-570. [CrossRef] [PubMed]

65. Ali, R.A.; Gandhi, A.A.; Dai, L.; Weiner, J.; Estes, S.K.; Yalavarthi, S.; Gockman, K.; Sun, D.; Knight, J.S. Antineutrophil properties of natural gingerols in models of lupus. JCI Insight 2021, 6. [CrossRef] [PubMed]

66. Wei, A.; Xiao, H.; Xu, G.; Yu, X.; Guo, J.; Jing, Z.; Shi, S.; Song, Y. Hyperoside Protects Human Umbilical Vein Endothelial Cells Against Anticardiolipin Antibody-Induced Injury by Activating Autophagy. Front. Pharmacol. 2020, 11, 762. [CrossRef]

67. Wang, T.; Zhou, H.; Xie, H.; Mu, Y.; Xu, Y.; Liu, J.; Zhang, X. Epigallocatechin-3-gallate inhibits TF and TNF- $\alpha$ expression induced by the anti- $\beta 2$ GPI/ $\beta 2$ GPI complex in human THP-1 cells. Int. J. Mol. Med. 2014, 33, 994-1002. [CrossRef] 